\title{
LONG-TERM VARIATION OF STRATOSPHERIC AEROSOLS OBSERVED WITH LIDAR FROM 1982 TO 2014 OVER TSUKUBA, JAPAN
}

\author{
Tetsu Sakai $^{1 *}$, Osamu Uchino ${ }^{1}$, Tomohiro Nagai ${ }^{1}$, Toshifumi Fujimoto ${ }^{2}$, Isao Tabata ${ }^{1}$ \\ ${ }^{1}$ Meteorological Research Institute, Japan Meteorological Agency, 1-1 Nagamine, Tsukuba, Ibaraki, 305- \\ 0052, Japan, *Email: tetsu@mri-jma.go.jp \\ ${ }^{2}$ Fukuoka Regional Headquarters, Japan Meteorological Agency, 1-2-36 Ohori, Chuo-ku, Fukuoka 810- \\ 0052, Japan
}

\begin{abstract}
The vertical distribution of stratospheric aerosols has been measured with lidars at the Meteorological Research Institute (MRI) over Tsukuba since 1982. After two major volcanic eruptions (Mt. El Chichón in 1982 and Mt. Pinatubo in 1991), stratospheric aerosol loading increased about 50-100 times compared with the background level which was observed for 1997 2000. From 2000 to 2012, a slight increase (5.3\% year-1) was observed by some volcanic eruptions. This long-term lidar data have been used for assessing of impact of the stratospheric aerosols on climate and the ozone layer.
\end{abstract}

\section{INTRODUCTION}

Stratospheric aerosols are submicrometer-size particles present persistently at altitude ranging from 10 to $30 \mathrm{~km}$. The amount of the stratospheric aerosols increases more than tenth of times after the large volcanic eruptions that inject $\mathrm{SO} 2$ gas into the stratosphere. Recently, several researchers $[1,2]$ have reported the increase of the stratospheric aerosol loading after 2000. The influence of the increase of the stratospheric aerosols is non-negligible on the Earth's radiation budget because they reflect solar light to space and reduce the incoming solar radiation [3, 4]. The stratospheric aerosols also affect ozone by serving reaction surface that result in ozone loss [5]. To understand the influences of stratospheric aerosol on the climate, we are necessary to monitor the vertical distribution of aerosols.

The MRI has been measuring the vertical distribution of the stratospheric aerosols over Tsukuba $\left(36.1^{\circ} \mathrm{N}, 140.1^{\circ} \mathrm{E}\right)$ with lidar [6, 7]. This paper reports the result of the observation over 30 years and studies the long-term variation of the stratospheric aerosols

\section{METHODOLOGY}

We have used six lidar systems for monitoring the stratospheric aerosol over Tsukuba since 1982. After the El Chichón volcano erupted on April 1982, we have started the measurement with a ruby lidar at a wavelength of $694.3 \mathrm{~nm}$. It was operated until 1987 when the influence of the El Chichón volcano on the stratospheric aerosols almost ceased [8]. After that time, we have employed Nd:YAG lidar systems operating at a wavelength of $532 \mathrm{~nm}$ since 1988. Since April 2002 we have employed unmanned system that continuously measures the aerosols in the stratosphere and troposphere for 24 hours.

We compute the backscattering ratio by employing the method of Fernald [9]. We assumed the extinction-to-backscatter ratio (lidar ratio) to 35-50 $\mathrm{sr}$ depending on the period according to the balloon borne measurements [10, 11]. The atmospheric density was derived from radiosonde observation launched $250 \mathrm{~m}$ northeast of the lidar (Tateno Aerological observatory). At the altitude range where radiosonde data was unavailable (usually above $35 \mathrm{~km}$ ) we used U.S. Standard Atmosphere (1976). In this study, we reanalyzed the data by taking absorption by ozone into account. The vertical profiles of ozone were obtained with ozonesonde launched from Tateno Aeorological Observatory every week.

\section{RESULTS}

Figure 1 shows the temporal variation of the vertically integrated aerosol backscattering coefficient (IBC) over Tsukuba from 1982 to 2012. The altitude ranges of the integrations are from $16.5 \mathrm{~km}$ and $30.5 \mathrm{~km}$. For the data taken with the ruby lidar $(694 \mathrm{~nm})$ from 1982 to 1987 , we converted the IBC values to those at $532 \mathrm{~nm}$ by using the conversion factor proposed by Jäger and Hofmann [12]. The orange tick marks on the top of Fig. 1 show the period of large volcanic 
eruptions with Volcanic Explosivity Index (VEI) $\geq 4$.

The values of IBC increased rapidly after the eruptions of El Chichón $\left(17.3^{\circ} \mathrm{N}, 93.2^{\circ} \mathrm{W}\right)$ on April 1982 and Mt. Pinatubo $\left(15.1^{\circ} \mathrm{N}, 120.4^{\circ} \mathrm{E}\right)$ on June 1992. The maximum values of IBC were $3.1 \times 10^{-3} \mathrm{sr}^{-1}$ on July 2 in 1982 and $5.8 \times 10^{-3} \mathrm{sr}^{-1}$ at February 22 in 1992. These values are 62 and 116 times larger than the minimum value $\left(5.01 \times 10^{-5}\right.$ $\mathrm{sr}^{-1}$ ) during the period from October 1997 to September 2001 when the influence of volcanic eruptions was at minimum (annual average of blue line in Fig. 1). The corresponding aerosol optical thicknesses were 0.16 and 0.29 , respectively, assuming the aerosol lidar ratio as $\mathbf{5 0}$ sr. After the eruptions the IBC value decreased to the background level over 6 years.

\section{DISCUSSION: Increase of IBC from 2000 to 2012}

The IBC value slightly increased from 2000 to 2012. The rate of increase was $1.06 \times 10^{-5} \mathrm{sr}^{-1}$ year ${ }^{1}\left(5.3 \%\right.$ year $\left.^{-1}\right)$. The increase of IBC after 2000 has been observed at Mauna Loa and Boulder in the United States [1] and Lauder, New Zealand [6]. Vernier et al. [2] suggested that the major reason for the increase was volcanic eruptions with $\mathrm{VEI} \geq 4$. We notice that the IBC between the tropopause and $16.5 \mathrm{~km}$ (not shown), which was unavailable from satellite observation, increased significantly during the period. The increase of the stratospheric aerosols cancel the global warming by the increase of anthropogenic carbon dioxide $[3,4]$. Thus, it is important to continue monitoring the stratospheric aerosol and studying the trend.

\section{REFERENCES}

[1] Hofmann, D. J., et al., 2009: Increase in background stratospheric aerosol observed with lidar at Mauna Loa Observatory and Boulder, Colorado, Geophys. Res. Lett., 36, L15808, doi:10.1029/2009GL039008.

[2] Vernier, J. P., et al., 2011: Major influence of tropical volcanic eruptions on the stratospheric aerosol layer during the last decade, Geophys. Res. $\quad$ Lett., $\quad 38, \quad$ L12807, doi:10.1029/2011GL047563.
[3] Solomon, S., et al., 2011: The persistently variable "background" stratospheric aerosol layer and global climate change, Science, 333, 866-870.

[4] Ridley, D. A., et al., 2014: Total volcanic stratospheric aerosol optical depths and implications for global climate change, Geophys. Res. $\quad$ Lett., 41, 7763-7769, doi:10.1002/2014GL061541.

[5] Kondo, Y., et al., 1995, Stratospheric ozone changes at $43^{\circ} \mathrm{N}$ and $36^{\circ} \mathrm{N}$ over Japan between 1991 and 1994, Geophys. Res. Lett., 22, 32233226, doi:10.1029/95GL03180.

[6] Uchino, O., et al., 1995: Extensive Lidar observations of the Pinatubo aerosol layers at Tsukuba $\left(36.1^{\circ} \mathrm{N}\right)$, Japan and Lauder $\left(45.0^{\circ} \mathrm{S}\right)$, New Zealand, Geophys. Res. Lett., 22, 57-60.

[7] Nagai, T., et al., 2010: Post Pinatubo evolution and subsequent trend of the stratospheric aerosol layer observed by mid-latitude lidars in both hemispheres, SOLA, 6, 69-72, doi:10.2151/sola.2010-018.

[8] Uchino, O., et al., 1988: Five-year lidar observational results and effects of the El Chichón particles on Umkehr ozone data, J. Meteor. Soc. Japan, 66, 635-643.

[9] Fernald, F. G., 1984, Analysis of atmospheric lidar observations: Some comments, Appl. Opt., 23, 652-653.

[10] Jäger $H$. and Deshler T., 2002: Lidar backscatter to extinction, mass and area conversions for stratospheric aerosols based on midlatitude balloonborne size distribution measurements, Geophys. Res. Lett., 29, 1929, doi:10.1029/2002GL015609.

[11] Jäger, H., and T. Deshler, 2003: Correction to "Lidar backscatter to extinction, mass and area conversions for stratospheric aerosols based on midlatitude balloonborne size distribution measurements", Geophys. Res. Lett., 30, 1382, doi:10.1029/2003GL017189.

[12] Jäger, H, and D. Hofmann, 1991: Midlatitude lidar backscatter to mass, area, and extinction conversion model based on in situ aerosol measurements from 1980 to 1987, App. Opt., 30, 127-138. 


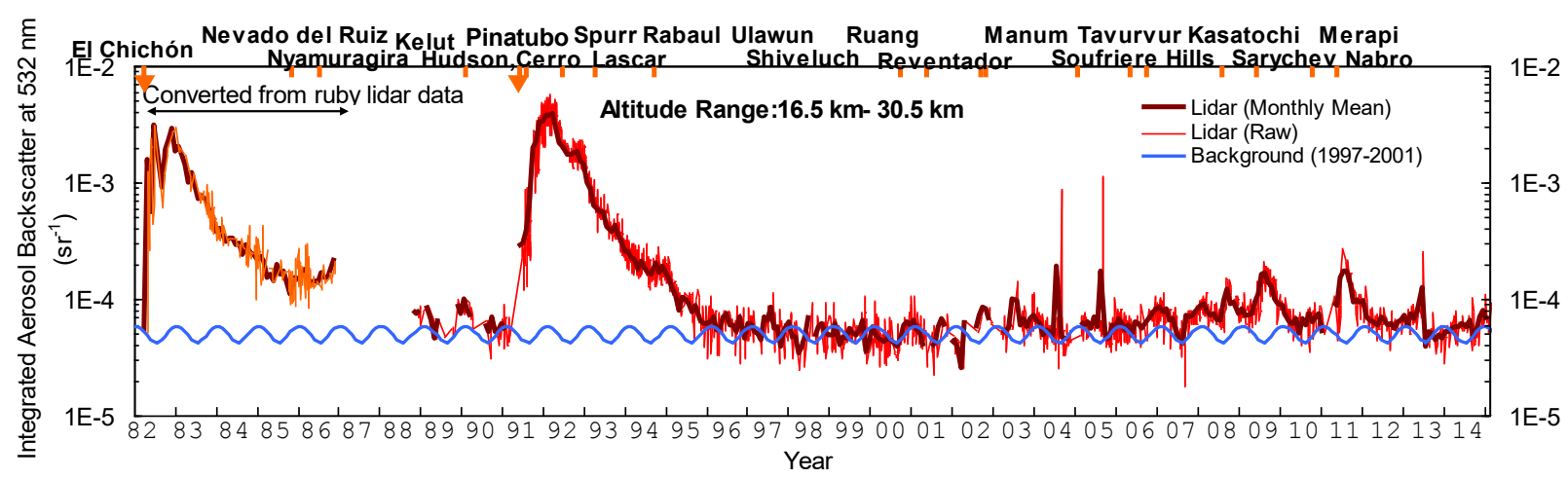

Fig. 1: Long-term variation of vertically integrated aerosol backscattering coefficient (IBC) at $532 \mathrm{~nm}$ between altitudes of 16.5 and $30.5 \mathrm{~km}$ over Tsukuba from 1982 to 2014. Thick black and thin red lines show the monthly mean and raw IBC values observed with the lidar. Blue line shows background values estimated by fitting a sinusoidal function to the observed values between 1997 and 2002. Orange tick marks on the top show the period of large volcanic eruptions. 